\title{
Fiscal Capacity and Inequality: Evidence from Brazilian Municipalities
}

\author{
Florian M. Hollenbach, Texas A\&M University \\ Thiago N. Silva, University of Mannheim
}

We argue that wealthy elites in democracies can limit their taxes by constraining the fiscal capacity of the state. Corrupting local officials and undermining fiscal capacity are some of the mechanisms by which high-income earners can lower their own tax liabilities, even when voters favor higher de jure levels of taxation. The incentive to undermine fiscal capacity is especially compelling when inequality is high, as the median voter is likely to support higher progressive taxation and redistribution. Using data from over 5,500 Brazilian municipalities, we show that localities with higher levels of inequality accrue less revenue from local property taxes. These results are robust to estimating a number of cross-sectional models as well as panel models with time and municipal fixed effects. Moreover, we show that municipalities with high levels of inequality are less likely to apply to a federal grant program to increase their capacity to collect taxes.

S cholars often presume that governments can enforce their preferred fiscal policies. This assumption has been empirically proven to be false, as governments' ability to collect taxes varies dramatically around the world. What explains these differences across countries, and who might have an interest in maintaining low levels of tax capacity that make evasion easier?

One of the key research questions in political economy is why some countries redistribute more than others (e.g., Acemoglu et al. 2015). In particular, why do many democracies with high levels of inequality redistribute far less than the Meltzer and Richard and Romer models would lead us to expect (Meltzer and Richard 1981; Romer 1975)?

Most of the research on redistribution starts with the assumption that states are capable of efficiently collecting taxes and redistributing income and, thus, focuses on examining the timing and impact of government decisions to implement redistributive policies. More recent studies have argued that political and economic elites in formerly autocratic regimes may undermine future political processes and limit political choices through institutional designs (Albertus and Menaldo 2014; Ardanaz and Scartascini 2013) or low state capacity (Acemoglu et al. 2015). Therefore, even if democratic polities are firmly in favor of redistributive policies, institutions and bureaucratic legacies may undermine the political and administrative process to de facto block redistribution.

In this paper, we investigate the idea that economic elites in democracies can undermine the state's ability to collect revenues and that they do so when levels of inequality are high. Specifically, we ask whether local economic and political elites can undermine efforts to increase taxation in democracies by inhibiting the ability to collect taxes.

We think of the state's capacity to enforce tax policies as endogenous and argue that when citizens vote for higher taxes, economic elites (the wealthy) have incentives to undermine the state's ability to collect taxes. The higher the equilibrium level of redistribution would be in a world with perfect tax collection, the stronger is the incentive for economic elites to erode the state's fiscal capacity. Weakening the state's administrative and tax capacity gives economic elites a mechanism with

Florian M. Hollenbach (fhollenbach@tamu.edu) is an assistant professor in the Department of Political Science at Texas A\&M University, College Station, TX 77843-4348. Thiago N. Silva (tnsilva@uni-mannheim.de) is a postdoctoral researcher at the Collaborative Research Center (SFB) 884 "Political Economy of Reforms," at the University of Mannheim, Germany, 68161.

Thiago N. Silva acknowledges funding by the German Research Foundation (DFG) via Collaborative Research Center (SFB) 884, "The Political Economy of Reforms" (project C1) at the University of Mannheim. Data and supporting materials necessary to reproduce the numerical results in the article are available in the JOP Dataverse (https://dataverse.harvard.edu/dataverse/jop). An online appendix with supplementary material is available at https://doi.org/10.1086 1704595.

The Journal of Politics, volume 81, number 4. Published online August 20, 2019. http://dx.doi.org/10.1086/704595

(C) 2019 by the Southern Political Science Association. All rights reserved. 0022-3816/2019/8104-0019\$10.00 
which to constrain policy choices and de facto levels of taxation outside the political system.

To investigate the theoretical argument, we use data on tax revenues from over 5,500 Brazilian municipalities. We show that, controlling for a variety of other factors, localities with higher levels of inequality raise less revenue from local property taxes. These results are robust to estimating a variety of cross-sectional models for 2000 and 2010, as well as panel models with time and municipal fixed effects. We also show that municipalities with high levels of inequality were less likely to apply to a federal grant program to increase their local tax capacity.

\section{FISCAL CAPACITY AND PUBLIC SPENDING}

Research in political science and economics often starts with the premise that in democratic polities, higher economic inequality ought to be associated with political demands for redistribution. Much of this work builds on the seminal model developed by Meltzer and Richard (1981), who showed that as the difference in mean income and income of the median voter increases, levels of taxation and redistribution should rise. The idea that democracy can and would be used for redistribution when inequality exists is not new, however, and goes at least as far back as Marx. While the Meltzer and Richard model is only one specific formalization, we expect rational voters in democracies to vote for higher taxation and redistribution as long as their marginal benefit from higher rates is positive. When taxes are linear or progressive, poorer citizens ought to prefer higher taxes than the rich. More so, if the benefit of government spending is higher for poor than rich voters, the optimal tax rate for the poor increases. Contrary to these expectations, empirically there is little evidence that inequality is associated with higher redistribution in democracies (e.g., Benabou 1996; Kenworthy and Pontussen 2005; Perotti 1996).

The lack of empirical support for the Meltzer and Richard (1981) model at the cross-national level is frequently noted. Some factors that possibly condition the relationship between inequality and redistribution are differences between social insurance and redistributive policies (e.g., Moene and Wallerstein 2001), institutional structures (e.g., Iversen and Soskice 2006; Persson and Tabellini 2003), religion (Scheve and Stasavage 2006), and ethnicity (Alesina and Glaeser 2004). More recently, scholars have argued that politics in authoritarian regimes can have lasting effects on fiscal policies, potentially long after the transition to democracy. Albertus and Menaldo (2014), for example, argue that autocratic elites can shape the institutional design of subsequent democracies to influence and shape future politics - that is, by influencing the "rules of the game" (Albertus and Menaldo 2014). Ardanaz and Scartascini (2013) contend that higher inequality leads to more legislative malapportionment, which makes enacting redistributive policies more difficult once the democratic regime is established.

While the design of political institutions with many veto points is one strategy to inhibit redistribution in democracies, undermining state capacity with the goal to keep the state from collecting revenue may be an equally compelling strategy. Economic elites may cripple the political process by stifling the state's ability to raise revenue. Theoretical models show that nondemocracies with higher levels of income inequality should see lower investment in state capacity (Besley and Persson 2011).

Similarly, Acemoglu and Robinson (2008) argue that possible changes in de jure political institutions give economic elites reasons to invest in subverting the state, to "capture democracy" and gain influence over policy decisions. An inefficient state with corrupt ("captured") bureaucrats may be a valuable strategy for economic elites to safeguard themselves against the political power of the masses (Acemoglu, Vindigni, and Ticchi 2011).

In line with these explanations, we argue that economic elites in democracies can exploit and further weaken the state's ability to collect revenue in an effort to block taxation demanded by voters. We contend that in democratic systems, rich or wealthy citizens can keep levels of taxation low, using both democratic and undemocratic means. The wealthy have incentives to ensure that their interests are (over)represented and that taxation is limited. One way to do so is by undermining the state's ability to collect taxes, that is, by constraining its fiscal capacity. Raising taxes is a complicated undertaking that involves collecting large amounts of data and requires a functioning and efficient bureaucracy (Besley and Persson 2009). Yet many governments cannot enforce the tax policies chosen by their governing bodies (Bird and Zolt 2008; Gordon and Li 2009). In such settings, wealthy residents may have strong incentives to undermine the state and limit their personal tax payments by lowering the state's ability to collect taxes.

To illustrate our argument, consider a theoretical society with rich $(r)$ and poor $(p)$ citizens, in which the median voter sets the de jure tax rate and is a member of the poor. Both wealth and income are taxable. Assume all revenue is used to finance a public good, such as education, or used as direct transfers. Assuming the median voter is decisive, she should vote for higher taxes until the marginal benefit from the financed public good is equal to her marginal cost of taxation. If taxes are not regressive and revenue is used for public goods or transfers, then the optimal tax rate at which the marginal 
benefit equals the marginal cost for the poor rises with increasing inequality.

As the tax becomes more progressive and spending benefits poor citizens more than the rich, the effect of inequality on the tax rate ought to be more pronounced. Thus, in accordance with the standard theory, if citizens vote rationally and based on income, we should see higher levels of de jure taxation in states with higher levels of inequality. On the other hand, the difference between pre- and posttax income of the wealthy elite would increase with higher levels of inequality. With this standard argument in mind, one could hypothesize that higher inequality leads to higher taxation (i.e., de jure tax rates) in democracies.

The distinction between de jure and de facto taxation is important for our theoretical argument. As taxes have to be administered and collected, de jure tax rates must not translate into the same de facto level of taxation. For example, with a de jure tax rate of $15 \%$, even the most efficient and effective tax administration does not achieve $15 \%$ realized revenue. We define the de facto tax rate as the actual share of the tax base that is collected in taxes. As the capacity of the tax administration decreases, the difference between de jure and de facto tax rates becomes greater.

In a democracy with weak administrative capacity and firm entrenchment of the wealthy in the political process, elites have strong incentives to undermine the state's ability to collect taxes. As outlined above, when inequality is higher, the de jure tax rate is likely to rise. When de jure tax rates increase, however, it becomes more profitable for economic elites to combat the state's ability to assess their tax liabilities or to influence the political process through other means. Alternative avenues for influence could include bribing local tax officials who are responsible for tax assessment, placing cronies in essential positions in the local bureaucracy, or impeding the purchase of necessary tools to make tax collection more efficient. Thus, in sufficiently weak states, we contend that economic elites can undermine tax collection, and the motivation to do so increases with higher levels of inequality.

We expect these tactics to be more likely in the context of highly progressive taxes. As a given tax becomes more progressive, the rich pay a higher share of tax revenue, which increases their motivation to fight tax collection. The difference between de jure and de facto rates should thus be more significant for more progressive taxes. Similarly, as spending benefits the poor more, we expect the relationship between inequality and the de jure taxation to become stronger, again raising incentives for elites to fight taxation.

Based on this theoretical argument, we develop our central hypothesis. Specifically, we expect that higher inequality is associated with less fiscal capacity, and therefore less de facto tax revenue. Our approach contrasts with the above outlined traditional hypothesis that higher inequality is associated with more tax revenue.

\section{RESEARCH DESIGN: THE CASE OF BRAZIL}

In this paper, we use data on tax collection from over 5,500 Brazilian municipalities to investigate the empirical argument. There are several reasons for using the case of Brazil and its municipalities as the unit of analysis.

The democratization of Brazil in the mid-1980s advanced the country socially and politically. There are now few barriers to voter registration (Limongi, Cheibub, and Figueiredo 2015), and compulsory voting ensures turnout is close to $80 \%$ (Nicolau 2012). Since its transition to democracy, Brazil has been known for its high levels of income inequality, making it one of the most unequal democracies in the world. Inequality has been surprisingly resilient and stable throughout the transition from the military dictatorship (1964-85) to the new democratic regime (Barros, Henriques, and Mendonça 2000; Souza and Medeiros 2015).

The relatively recent transition to democracy and the persistence of inequality are two reasons that make it an intriguing case with which to investigate our argument. If the standard arguments were correct, we would have expected a stark increase in redistribution and taxation after Brazil's democratization in the 1980s. The argument we make above is one possible explanation for why this has not been the case.

\section{The case for studying municipalities}

The Brazilian federative union is composed of 26 states and the federal district. Brazil has 5,570 municipalities, its lowest level of government, which have more political autonomy than localities in any other Latin American country (Nickson 1995; Rodríguez and Velásquez 1995). Most political responsibilities lie with the federal union or states, yet the 1988 constitution gave substantial autonomy to the municipalities (Andrade 2007; Baiocchi 2006; Samuels 2004). In line with the increase in political authority, municipalities can institute and collect taxes within their jurisdiction and use the revenue to implement local policies (Andrade 2007; Arretche 2004).

The municipalities are largely funded by transfers from the federal and state governments. These transfers have significantly declined, however, leading to budget shortfalls and low revenues in many municipalities. One of the most critical local tax sources is the taxation of property and land in urban areas, the Imposto predial e territorial urbano (IPTU): the urban land and building tax. This tax is solely available to municipalities, and its importance as a local revenue source has increased significantly (De Cesare and Ruddock 1999). 
We aim to investigate whether elites use low levels of administrative capacity, as well as undermine it further, to limit their taxation. To do so, we focus on the case of the property tax in Brazilian municipalities. While the IPTU is one of the principal sources of local revenue in Brazil (property taxes represent an average of $30 \%$ of the local tax revenue) (De Cesare and Ruddock 1999; Smolka and Furtado 1996), comprehensive studies of this tax indicate that it is still overlooked and has unrealized potential (Afonso and Araújo 2006; Afonso, Araújo, and Nóbrega 2013; De Cesare and Ruddock 1999).

While property taxation is a tax on wealth, we believe our theoretical argument, which is primarily about income inequality, still applies here. The IPTU is the second most important local revenue source available to municipalities (Afonso et al. 2013) and has the potential to be highly progressive. Therefore, if voters observe high levels of inequality and as a result demand more taxation and spending, the IPTU is the primary local mechanism to raise these funds. Moreover, administration of the property tax requires high administrative capacity (Bahl and Martinez-Vasquez 2008; Kelly 2013), making it a worthwhile endeavor for elites to engage in actions to undermine the collection of these taxes.

The distributive effects of the tax and relevant spending instruments are similarly important. We have strong reason to believe that the property tax is progressive by design, and that municipal spending largely benefits the poor. First, after the new constitution was enacted in 1988, a progressive property tax system was considered a potential policy mechanism to overcome urban social inequalities and attain equity (Carvalho 2015; De Cesare 2012; De Cesare and Smolka 2004). After a period of legal ambiguity, a constitutional amendment was passed in 2000, that explicitly allowed progressive tax rates for the IPTU (Carvalho 2013). In reality, however, the IPTU has been found to be a regressive tax (Afonso et al. 2013; Carvalho 2006, 2015).

Several causes for the regressivity of the IPTU have been suggested. Directly in line with our argument, one significant reason for its regressive nature is the poor collection of the IPTU. This is due to administrative mismanagement, administrative inefficiency, the high cost of maintaining the property register, and the discrepancy between the government's real estate evaluations and their market value (Carvalho 2006, 2015; De Cesare 2005). Tax exemptions for large companies and tax evasion are also responsible for the high regressivity (Carvalho 2006; De Cesare and Smolka 2004).

As De Cesare (2005) and Afonso et al. (2013) note, changes in IPTU rates depend on the approval of councilors in the municipal legislature. Not surprisingly, property owners in wealthier areas regularly resist higher rates, and even more so if the revenue will be invested in poorer areas of the municipality (Afonso et al. 2013; De Cesare 2005). Similarly, organized groups of landowners tend to pressure public authorities to minimize their fiscal burden (Afonso et al. 2013). This is exacerbated by the fact that new valuations of properties have to be approved by the municipal legislatures, giving the wealthy an avenue to undermine the administrative process of tax collection (Carvalho 2013). Thus, at least part of the regressivity of the IPTU is due to differences in the de jure and de facto tax rates.

If properly enforced, the IPTU has the potential to be redistributive and the exact mechanisms outlined in our theoretical argument above, that is, elite resistance against higher taxes, are at least partially responsible for its regressivity. In addition to the potential progressivity of the tax itself, government spending at the municipal level primarily benefits the poor. In other words, the marginal benefit of additional spending is higher for the poor than the rich. For example, the most significant share of local budgets is spent on education, with health spending being second. Municipalities primarily finance preschools and primary schools as well as education infrastructure and school lunches (Gadenne 2017). ${ }^{1}$ While not directly redistributive transfers, spending on these goods, we contend, is redistributive in nature and has greater benefits to poorer segments of society.

In line with our argument, Gadenne (2017) finds that investments allocated to modernize local tax administrations do increase tax revenue. The additional income is spent on the provision of public goods, with three-quarters of the extra revenue going toward public education. This results in an $8 \%$ increase in locally funded school infrastructures and 6\% more children enrolled in municipal schools (Gadenne 2017).

\section{Measuring fiscal capacity using the property tax}

Property taxes are difficult to enforce for both administrative and political reasons (Bahl and Martinez-Vasquez 2008; Kelly 2013). According to Kelly (2013), we can decompose total property tax revenue into two parts. First, the total level of potential revenue, which equals the tax rate applied to the total tax base, that is, de jure tax rate above. The second, equally important, determinant of total revenue is made up of "administration-related variables." These variables are the coverage ratio, that is, the share of properties captured in the municipality's registry; the valuation ratio, that is, the ratio of valuation in the taxpayer registry to the market valuation of

1. According to data from the Brazilian Ministry of Finance (National Treasury [DFOFM] 2017), the share of public goods spending that goes to education and health grew from $25 \%$ and $11 \%$ in 1990 to $34 \%$ and $17 \%$ in 2000 , and $41 \%$ and $32 \%$ in 2010 , respectively. 
properties; and the collection ratio, that is, the percentage of levied taxes that are collected. While tax rates and the base are both relevant determinants of the tax revenue collected by the state, the administrative capacity is fundamental for property taxes to raise significant revenue (Bahl and MartinezVasquez 2008; Kelly 2013).

Calculating IPTU liability (i.e., the valuation) requires several types of information, such as property size, location of the property, property use, front and backyard area, property construction standard, and so forth (Carvalho 2006). Before valuation, properties must be registered in the municipal cadaster. Carvalho (2006) estimates that only $60 \%$ of the urban real estate in Brazil is registered. Another important aspect of property tax collection is the frequency of assessment, that is, how often does the administration update/assess the value of properties? The Brazilian central government recommends evaluating property values every five years, with yearly adjustments. The guidelines do not seem to be regularly followed, however. For example, while Porto Alegre in the 1990s had more regular assessments than other municipalities, the assessed values of residential properties were only $19.2 \%$ of their sales prices (De Cesare 2012).

While it is almost impossible to accurately and reliably measure fiscal capacity, we use realized property tax revenue as a proxy for local fiscal capacity. We assume that given the control variables included in the regression models below, at least some of the variation in the policy-related variables is held constant across our cases. For example, we include controls for local GDP, population size, and share of the rural population, which ought to explain differences in the tax base. We add controls for revenue needs (i.e., transfers from the federal government, oil revenue) and political determinants (left-leaning mayors), which should at least partly account for differences in tax rates. ${ }^{2}$ Finally, we discuss some robustness checks based on smaller samples with more direct measures of administrative capacity.

Kelly $(2013,147)$ identifies the incompleteness of property registries (cadasters) as the most pressing administrative issue when it comes to property tax collection in developing countries, with a lack of "necessary political will to collect and enforce the property tax" (emphasis added) as an additional major hurdle. Anecdotal evidence suggests that municipalities in Brazil find it difficult to increase their administrative capacity. As De Cesare and Ruddock (1999) point out, wherever localities aim to increase the quality of assessment and revenue of the property tax, they are met with strong opposition. Qualitative evidence of tax fraud and

2. Unfortunately, complete data on tax rates at the local level are not available. incompetence in local government tax collection is easy to find. For example, in 2014, the public prosecutor's office of São Paulo was investigating companies suspected of carrying out a fraud scheme in the city's IPTU collection in partnership with tax collectors (IPTU inspectors). The inspectors calculated the correct tax but recorded only half the area when visiting buildings. The other half of the tax was paid as a bribe to the inspectors. While the bribe was paid once, the scheme guaranteed a tax bill that was $50 \%$ of the de jure amount for all subsequent years (Estadão 2014).

Similarly, a group of employees in the São Paulo City Hall was accused of fraud and irregularities concerning charges of the Service Tax and the IPTU. Members of the group defrauded the IPTU, by making changes to the cadaster, which was estimated to have cost city hall about half a billion Brazilian reais (approximately US\$160 million in today's value) (G1-Globo 2013).

Other examples of fraud and local difficulties with tax collection include charges of public servants making improper changes to the collection system (G1-Globo 2012), fraud schemes in the city of Campinas (collection of less than $10 \%$ of property values), and the municipality of Taboão da Serra (Folha de São Paulo 2011). These tax evasion schemes cost at least R\$15 million for Campinas (Folha de São Paulo 1999) and caused a minimum loss of $\mathrm{R} \$ 10$ million to Taboão da Serra, a municipality with more than 250,000 inhabitants (Folha de São Paulo 2011).

Some readers may question the use of property tax at the local level as the unit of analysis. The majority of taxes in Brazil are levied at the federal level, which raises the question whether elites would try to undermine local capacity. We believe that the collection of local property taxes is nevertheless highly relevant for this study. First, these taxes, if properly enforced, are likely to be progressive. Based on the theoretical argument, all else equal, elites ought to prefer paying lower property taxes. Additionally, undermining the local property tax administration in the respective municipality is most likely easier and less costly than attempting to do so at the federal level. Thus, the marginal benefit of undermining tax capacity may be highest at the local level. While we lay out a general argument above, we believe that if it holds true, we should find evidence of these processes at the local level. Given the large variation in inequality and tax revenues in municipalities across Brazil, we think these represent an excellent test case for our argument.

\section{EMPIRICAL STRATEGY: DATA AND MODELS}

To investigate whether high-income earners use low levels of fiscal capacity to limit redistribution and taxation in highinequality municipalities, we collected data on tax revenues, 
political, and socioeconomic variables for the years 1990, 2000, and 2010 from different sources. The dependent variable, our proxy for fiscal capacity at the local level, is the property tax revenue collected by municipalities. The measure of revenue collection comes from the Brazilian Ministry of Finance, released by the National Treasury Secretariat, and is made available by the Institute of Applied Economic Research (IPEA 2016). ${ }^{3}$

Brazil exhibits high geographic variation in both inequality and tax collection. Our preferred measure of income inequality in the municipalities, the Gini coefficient, ranges from 0.28 to 0.8 in Brazil for 2010. The use of subnational data allows us to hold many variables constant across observations. For example, differences in the political system should not influence our results.

We include several control variables in the regression model to account for possible confounders and partial out tax rates and tax base. First, we add a control for municipal GDP to account for the fact that higher inequality may be caused by increasing incomes, while more affluent municipalities have a larger tax base and are likely to be more efficient at revenue collection. We also control for population size. Brazilian municipalities are heterogeneous regarding their size, economic condition, and capacity to tax. Studies have shown that municipal size is positively correlated with property tax revenue (Avellaneda and Gomes 2014; Gomes, Alfinito, and Albuquerque 2013). Both of these measures were gathered from the Brazilian Institute of Geography and Statistics (IBGE 2016).

Since municipalities are only allowed to collect property taxes from urban areas, it is pertinent for us to account for differences in urbanization. Hence, we control for the share of the population living in rural areas. We also include a measure of municipal spending on housing and urbanization. The inclusion of this variable is important, as spending on housing and urban development affects real estate evaluations and increases the base for calculating the IPTU tax. A second relevant fiscal variable included in our models is the level of transfers from both the federal and state governments to each of the municipalities (Brollo et al. 2013; Litschig and Morrison 2013). Data on transfers and housing spending were gathered from the Institute of Applied Economic Research (IPEA 2016). Additionally, we control for

3. Based on personal communication with IPEA, some ambiguity about the meaning of zeros in the IPTU revenue data exists. It is possible that some observations with a value of zero are actually missing data, while for other observations the zeros are meaningful values that indicate zero revenue. This issue mostly applies to the panel model. We use the original data in the main text but undertake additional robustness checks in appendix F. municipal revenue from oil exploration (royalties). Royalty payments made to municipalities in which oil has been discovered and explored increased from R\$167 million in 1997 to $\mathrm{R} \$ 4.7$ billion in 2008 (Monteiro and Ferraz 2012). Royalty payments are associated with an increase in the number of municipal employees (Monteiro and Ferraz 2012) and municipal revenues (Caselli and Michaels 2009). Similar to intergovernmental transfers, we expect that royalties from oil exploration undermine local governments' incentives to increase their own revenue capacity and may also affect inequality.

In addition, in our cross-sectional models, we include an indicator variable with a value of 1 if the mayor of the municipality is from a left party and 0 otherwise. The inclusion of this variable is an attempt to understand whether leftleaning parties are more likely to raise the fiscal capacity/redistributive taxation and whether they are able to achieve this goal. Given our theoretical argument, we do not expect leftleaning party governance to have a strong effect on de facto tax revenue. Additionally, this control may partial out some of the differences due to de jure tax rates. Political data were collected from the Superior Electoral Court (TSE do Brasil 2016), and leftist parties were classified based on surveys and roll-call vote studies of Brazilian legislators (Power and Zucco 2009, 2012; Saiegh 2015; Samuels and Zucco 2014).

We were able to collect these variables for the years 2000, 2010, and approximately 1990. We first estimate crosssectional models for both 2000 and 2010. We estimate standard ordinary least squares (OLS) regressions for the crosssectional models but calculate standard errors clustered by states. The dependent variable (IPTU Revenue) and the independent variables Housing, GDP, Transfers, Oil Revenue, and Population were log transformed to reduce the rightskewness of their distributions. ${ }^{4}$

In addition to the cross-sectional models for two time periods (2000 and 2010), we also estimate a panel model for 1991, 2000, and 2010, in which we include municipal and year fixed effects. Using the unit-specific intercepts, we aim to control for unobserved confounders that do not vary over time or across units.

\section{EMPIRICAL ANALYSIS: RESULTS AND DISCUSSION}

Figure 1 illustrates our general findings in the cross-sectional models. The plot displays the coefficient estimates for our cross-sectional model for 2010 with standard errors clustered by state. ${ }^{5}$

4. To avoid creating missing values, prior to taking the log we add 1 to the values of IPTU, Housing, Oil Revenue, and Transfers variables.

5. Table A.1 in the appendix presents the estimation results for six different models for the 2000 and 2010 data. All models were estimated 


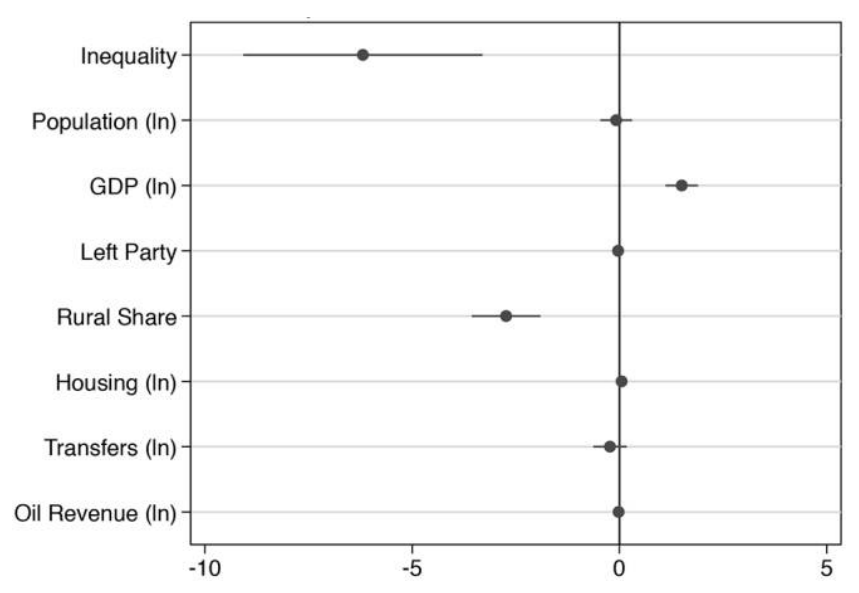

Figure 1. Coefficient estimates from model 6 of table A.1 in app. A. Crosssectional model for 2010 with nonimputed data. Standard errors clustered by state. Dependent variable: IPTU revenue in Brazilian reais (logged). The negative and significant estimate for Gini indicates that, as inequality increases the state's ability to raise revenue from citizens decreases substantially.

Our results consistently lend support to our hypothesis. Particularly, the coefficient for inequality (Gini) is estimated to be negative and is statistically significant in all models. Higher inequality is associated with lower property tax revenue, that is, as inequality rises a municipality's ability to collect IPTU from its citizens decreases. For example, according to the results displayed in figure 1, holding all covariates at their median value and increasing inequality from the 25 th percentile value $(0.45)$ by one standard deviation (to 0.52 ) is associated with a decrease in logged IPTU revenue from 10.92 to 10.49 .

In line with our expectations, the coefficient for GDP is precisely estimated and positive, which indicates that richer municipalities raise more revenue from property taxes. In contrast, the larger the share of the population living in rural areas, the lower the revenue from the IPTU.

Higher population size may be associated with lower revenues. The estimates for intergovernmental transfers are also not precisely estimated in models with clustered standard errors. The results do indicate that municipalities that are more dependent on transfers collect lower revenues from the IPTU. These results are similar to our findings for Oil Revenue. Throughout all models, the coefficient for oil revenue is estimated to be negative, but the precision of the estimates varies across the different models. Also as expected, mayors from

using OLS. Models 2 and 4 were estimated computing robust standard errors, and models 3 and 6 were estimated computing standard errors clustered at the state level. We also estimate all models based on data that are multiple imputed using Gaussian copulas (Hoff 2007). The results are shown in table A.2 in the appendix and support the results presented here. left-leaning political parties are not associated with higher revenues: the coefficient for leftist party mayor is very small, inconsistent, and estimated with high uncertainty. ${ }^{6}$

In appendix B (apps. A-F are available online), we provide additional evidence for the robustness of these results by adding several potentially relevant controls and estimating bivariate models without controls. The results do not change substantially for any of these specifications. The effect of inequality remains negative and significant when we add controls for voter turnout, competitiveness of the mayoral race, other municipal tax revenues, share of the population vulnerable to poverty, ${ }^{7}$ share of municipal GDP produced in the industrial sector, number of families that benefit from the cash transfer program (Bolsa Família), or the size of the cash benefits. The estimated effect of inequality is negative and statistically significant in all of these specifications, except when we include total logged cash benefits paid out and cluster standard errors by state. In that particular model, the coefficient on inequality is significant only at the $10 \%$ level. Finally, the results remain substantially the same when we add GDP growth in the previous decade to our cross-sectional models.

To provide further evidence for the robustness of our results and alleviate concerns about the dependent variable, we also estimate several models with other potential measures of fiscal capacity at the municipal level. For some of these, however, the sample size is reduced significantly. The results are presented in appendix C. First, we show that the cross-sectional results are robust to calculating our dependent variable as the ratio of IPTU revenue to municipal GDP or as a ratio to total municipal tax revenue. We also provide the results when using revenue from a different local tax source (ITBI, a tax on property transfers) as the dependent variable. The results do not change substantially.

Finally, we create a variable measuring the ratio of registered properties for which the property tax was paid to total registered properties (collection rate). These data are collected for 1998. While imperfect, we use this measure as an alternative dependent variable for our cross-section of 2000 (the closest year for which we have data). Again, the relationship with inequality is estimated to be negative and significant.

So far, we have shown that across different municipalities, higher inequality is robustly associated with less municipal

6. As an additional robustness check, table A.3 in the appendix displays the results from four spatial autoregressive models. Overall, the results from the spatial models are consistent with the findings presented above.

7. Variable is defined as the share of the population with incomes less than $\mathrm{R} \$ 255.00$ a month. 
revenue collected from property taxation. These findings lend support to our theoretical argument that in higherinequality districts, wealthy elites undermine the state's ability to collect taxes. The results are robust to including zero or a large number of potential confounders as controls.

Nevertheless, other potential factors may affect both tax capacity and inequality. In this section, we present evidence based on a simple panel model at the municipal level for 1991, 2000, and 2010, with both municipal and year fixed effects. ${ }^{8}$ By including both municipal and time fixed effects we can control for unobservables at the municipal level that do not vary over time, as well as shocks in time that do not change across the different municipalities. ${ }^{9}$ Given these additional parameters, the results from the three-period panel model can serve as an additional check on the results presented above.

We specify the following model for the three-period panel data:

$$
y_{i t}=\alpha_{i}+\gamma_{t}+\beta \mathbf{X}_{\mathrm{it}}+\delta G_{i t}+\epsilon_{i t},
$$

where $\alpha_{i}$ and $\gamma_{t}$ are municipality- and year-specific intercepts, $\mathbf{X}_{i t}$ is a matrix of time-varying covariates, and $\beta$ is a vector of the corresponding estimated coefficients. The term $G_{i t}$ is the main variable of interest, the Gini coefficient for municipality $i$ at time $t$. Based on our theoretical argument, we expect its coefficient $\delta$ to be negatively signed. We present the results based on standard errors clustered at the state level.

Figure 2 displays the results from the three-period panel model. Growth in population and transfers over time are associated with higher levels of tax revenue, and the $95 \%$ confidence intervals do not include zero. The coefficients for GDP, share of the rural population, and logged spending on housing are very close to zero and not significant at standard levels. Most importantly, the coefficient for inequality is negative, and its $95 \%$ confidence interval does not cover zero. An increase in inequality over time is associated with less municipal revenue from property taxes. This finding gives additional credence to the theoretical argument. ${ }^{10}$

8. Since several variables are not available for 1990 , we use 1991 as our earliest observation. In addition, we could not find data for municipal GDP for the early 1990s. We thus have to rely on a GDP measurement from 1985 in the panel data for 1991.

9. Since inequality within a municipality may also create incentives to redraw municipal boundaries, we conduct an analysis using a subsample based on municipality age. The results, presented in app. E, indicate that a possible split of municipalities due to high inequality does not seem to be driving our results.

10. Some of the municipalities in our sample were created after 1990 We therefore subset the data to those municipalities created prior to 1985 . The results remain the same if we do not subset.

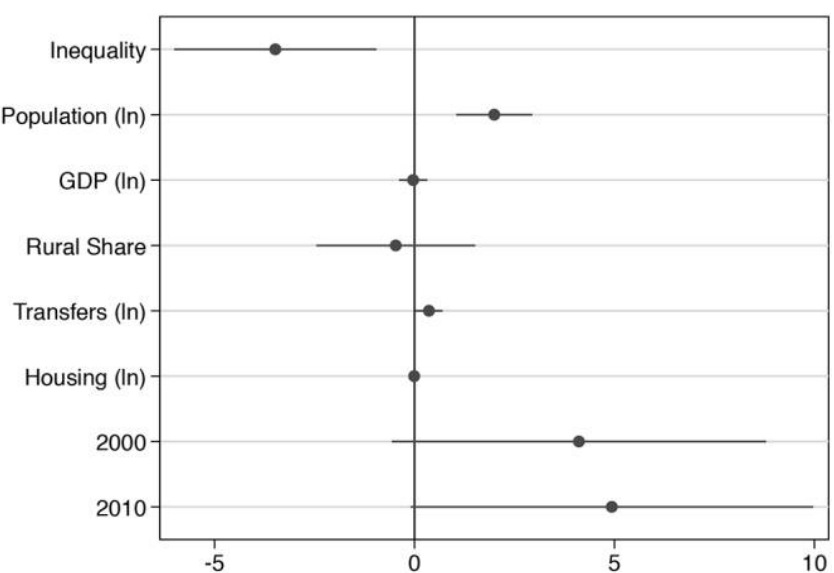

Figure 2. Coefficient estimates from model 1 of table D.1 in app. D. Panel model $(1991,2000,2010)$ with year and municipal fixed effects, standard errors clustered at the state level. Dependent variable: IPTU revenue in Brazilian reais (logged). The results are consistent with the cross-sectional model, indicating that increases in inequality are associated with lower capacity to collect taxes.

As a robustness check, we estimate the same model in a two-period panel for 2000 and $2010 .{ }^{11}$ Surprisingly, once we add year fixed effects, the coefficient for inequality is estimated to be positive in the two-period model with controls (2000 and 2010). This suggests that something changed in high inequality municipalities between 2000 and 2010. It is possible that the introduction of the federal cash benefits program Bolsa Família in 2003 led to these changes, though there is no clear way to test this. Since Bolsa Família was started in 2003, we cannot include it as a covariate in the panel models. As we discussed above, however, the results in the cross-section for 2010 are robust even when controlling for Bolsa Família benefits. ${ }^{12}$

As with the cross-sectional model, we estimate the threeperiod panel model as a bivariate model with unit and year fixed effects. We also add a linear time trend and a quadratic time trend to the three-period panel model. The results remain the same. Finally, we estimate the two-period panel model using data on the collection rate (i.e., the ratio of paid to levied taxes) for 180 municipalities. These data were originally collected by Carvalho (2017). Our general finding: a significant and negative relationship of inequality with fiscal

11. For the two-period panel model, we subset the data to municipalities created before 2000 (results shown in table D.1 in the appendix).

12. We thank an anonymous reviewer for alerting us to the possible effects of the Bolsa Família program. Table D.1 in the appendix also displays the results for both panel models when the data are multiple imputed using Gaussian copulas (Hoff 2007). The results are mostly unchanged, and in fact, the effect of inequality on property tax revenue is estimated to be stronger. 
capacity remains. On average, the greater the inequality, the smaller the IPTU collection rate. The results of these robustness checks are presented in appendix D.

\section{SELECTION ON UNOBSERVABLES}

In this section, we briefly discuss a sensitivity analysis of the regression results, as suggested by Oster (2019). We estimate how strong selection on unobservables compared to observables would have to be if the effect of inequality is due to bias. Two concepts are required. The first is the "relative degree of selection on observed and unobserved variables" $(\delta)$, that is, how much more important are the variables included in the regression models compared to unobservables. Generally, Oster (2019) suggests considering results to be robust if $\delta>1$. Second, $R_{\max }$ is defined as the maximum attainable $R^{2}$ for the particular regression, if all relevant variables were included. Of course, the most conservative test is with $R_{\max }$ set to one, the highest possible $R^{2}$. Based on empirical evidence using the results of randomized experiments, Oster (2019) suggests that a $R_{\max }$ of 1.3 times the $R^{2}$ from the relevant regression might be more appropriate. We estimate $\delta$ for each of three regression models of interest using the highest possible values of $R_{\max }, R_{\max }=1$.

The relevant values are displayed in table 1 . The results imply that it is unlikely that our results are due to selection on unobservables, as the estimated $\delta$ for all three models are above the critical value of 1 , even when we use the maximum possible value of one for $R_{\max }$.

\section{APPLICATIONS TO CAPACITY-BUILDING PROGRAM}

The empirical analyses and the robustness checks in the previous section have provided evidence in line with our theoretical argument. Nevertheless, questions may remain with regard to our dependent variable and the identification of the theoretical mechanism. In this section, we investigate if inequality levels influenced whether municipal governments applied for grants to improve their tax administration.

In 1997, the Brazilian federal government initiated the Modernization Program of the Tax Administration (PMAT), with

Table 1. Selection on Unobservables

\begin{tabular}{|c|c|c|c|}
\hline & 2000 & 2010 & Panel Model \\
\hline$R_{\max }=1$ & $\delta=1.92$ & $\delta=2.62$ & $\delta=4.82$ \\
\hline
\end{tabular}

Note. Dependent variable: IPTU Revenue in Brazilian reais (logged). Test for 2000 from cross-sectional model 3 of table A.1 in app. A. Test for 2010 from cross-sectional model 6 of table A.1 in app. A. Test for panel model from panel model 1 of table D.1 in app. D. the goal of improving municipalities' tax administration. The foremost objective of the program was to increase municipalities' revenues by improving tax registration and collection processes, modernizing taxpayer services, and enhancing municipalities' fiscal responsibility and capacity (Afonso et al. 1998; Guarneri 2002). The program focuses on the modernization of information technology, computer equipment, training of human resources, specialized technical services, and the physical infrastructure of municipalities' public administration (Corrêa 2009; Guarneri 2002).

The financial funds of the program are provided to the municipalities by the Brazilian Development Bank (BNDES) through credit lines opened by BNDES financial partner institutions. The current financing amount limit is either a maximum of $\mathrm{R} \$ 60$ million per municipality or $\mathrm{R} \$ 36$ per capita (the financing accepted is based on the lower value of these criteria) (Corrêa 2009).

Gadenne (2017) has taken advantage of the program to show that higher levels of fiscal capacity - and, ergo, local tax revenue - cause positive changes in municipal education infrastructure. If our argument is correct, we should find that municipalities with higher levels of inequality are less likely to apply to the program (even though their revenues are lower). We, therefore, estimate the probability that a municipality joins the PMAT program until 2010 as a function of its inequality level (Gini coefficient) and controls included in our previous models (all measured in 1991). We also include municipal revenue raised from IPTU collection as a control. According to our argument, the elites' constraint on the state should be stronger under higher levels of inequality. Thus, we expect that the greater the municipality's inequality, the lower the likelihood it will apply to PMAT.

As shown in table 2, the results support this expectation. Across linear probability, logit models, and when we cluster standard errors by state (models 2 and 4), the coefficient on inequality is negative and precisely estimated. Greater inequality appears to be associated with a lower likelihood of application to PMAT, a finding that is also reflected in the work by Gadenne (2017). For space reasons we omit the control variables from the table, but full results are presented in appendix C.

These results are consistent with our expectation that more unequal municipalities will have a lower capacity to collect taxes. Although PMAT currently reaches all regions of Brazil, the program is heavily concentrated in the less unequal south and southeast regions of the country (Corrêa 2009; Grin 2014). While the south and southeast have received $73.4 \%$ of all established contracts in 2009, municipalities in the north and northeast regions of Brazil (more unequal) account for only $3.8 \%$ of the contracts (Grin 2014). After 13 years, the fact 
Table 2. Municipal Applications to the Capacity-Building Program (PMAT)

\begin{tabular}{ccccc}
\hline & \multicolumn{4}{c}{ Dependent Variable: PMAT Application } \\
\cline { 2 - 5 } & Model 1 & Model 2 & Model 3 & Model 4 \\
OLS & OLS & Logit & Logit \\
\hline \multirow{4}{*}{ Gini } & & & & \\
& $-.242^{* * *}$ & $-.242^{* * *}$ & $-2.786^{* *}$ & $-2.786^{* *}$ \\
& $(.050)$ & $(.070)$ & $(1.166)$ & $(1.230)$ \\
\hline
\end{tabular}

Note. Standard errors in parentheses. Two-tailed test. Dependent variable: indicator of PMAT application $(1=$ municipality applied to PMAT; $0=$ municipality did not apply to PMAT). All four models include controls for IPTU revenue (logged), population (logged), GDP (logged), rural share, transfers (logged). Full table is displayed in table C.6 in app. C. Model 1 and model 3 with robust standard errors; model 2 and model 4 with standard errors clustered by state.

${ }^{*} p<.1$.

${ }^{* *} p<.05$.

${ }^{* * *} p<.01$

that only 369 municipalities (6.63\% of the Brazilian municipalities in 2011) participate in the PMAT reveals a low acceptance of the program among municipal governments in general (Grin 2014).

\section{CONCLUSION}

Some of the most famous formal models in political economy make the prediction that taxation in democracies ought to increase with inequality (Meltzer and Richard 1981; Romer 1975). Yet in many cases, scholars do not find the stated relationship to be true. We argue that this may be explained by wealthy elites undermining the state's ability to collect taxes in highly unequal democracies, especially when the state's capacity is already limited.

To investigate this proposition, we use data on property tax revenue, inequality, and other economic variables from over 5,500 municipalities in Brazil. Using cross-sectional, as well as panel models, and undertaking a variety of robustness checks, we show that municipalities with higher levels of inequality have lower levels of fiscal capacity/raise less revenue from the local property tax. The evidence is consistent with our theoretical argument. We do acknowledge, however, that we cannot yet identify the exact causal mechanism and that other potential explanations are possible. On the other hand, our results are strengthened by the fact that municipalities with higher inequality were also significantly less likely to apply for federal programs that could aid their tax collection efforts.

If wealthy elites do actively undermine tax administration in highly unequal societies, this should have consequences for how we view democratic policy making and the delivery of public goods. A democratic political system is no panacea: even if the will of the voters may be translated into policies, the state is not always able to properly enforce the policy choices made. On the other hand, it may be that as democracies stabilize and become further removed from their authoritarian origins, they can slowly diminish the influence of elites and increase capacity. This possibility should be further investigated in future cross-national work. Similarly, as we argue in the paper, we think that our findings are generalizable to national level politics. Yet, subsequent studies ought to investigate whether the lack of evidence in line with the Meltzer and Richard (1981) model cross-nationally can be explained by the theoretical argument made here.

Finally, future research should further consider the exact mechanisms by which economic elites can undermine the state's capacity to collect revenues and enforce policies. Better understanding of these processes will help us gain a better grasp of the difficulties of policy making in (young) democracies and thus the threats to their existence. Additionally, further research ought to investigate how limited state capacity can influence the nexus between voters and politicians. For example, low levels of capacity may impact voters' preferred policies and evaluation of politicians, especially when it comes to taxation and public goods.

\section{ACKNOWLEDGMENTS}

We thank Pedro de Carvalho Júnior and Eduardo Grin for their valuable help with the data. We also thank Pablo Beramendi, Jose Cheibub, Eunyoung Ha, Jan Pierskalla, and Ken Scheve for valuable feedback. We also thank three anonymous reviewers and the editorial team at the Journal of Politics for their feedback and help on this paper. Previous versions of this manuscript were presented at the 112th annual meeting of the American Political Science Association in Philadelphia and at the workshop in political economy and political violence at Texas A\&M University.

\section{REFERENCES}

Acemoglu, Daron, Suresh Naidu, Pascual Restrepo, and James A. Robinson. 2015. "Democracy, Redistribution, and Inequality." In Anthony B. Atkinson and François Bourguignon, eds., Handbook of Income Distribution, vol. 2. Amsterdam: Elsevier, chap. 21, 1885-1966.

Acemoglu, Daron, and James Robinson. 2008. "Persistence of Power, Elites, and Institutions.” American Economic Review 98 (1): 267-93.

Acemoglu, Daron, Andrea Vindigni, and Davide Ticchi. 2011. "Emergence and Persistence of Inefficient States." Journal of the European Economic Association 9 (2): 122-208.

Afonso, José Roberto, and Erika Amorim Araújo. 2006. "Local Government Organization and Finance: Brazil." In Anwar Shah, ed., Local Governance in Developing Countries. Washington: World Bank, 381-418. 
1444 / Fiscal Capacity and Inequality Florian M. Hollenbach and Thiago N. Silva

Afonso, José Roberto, Erika Amorim Araújo, and Marcos Antonio Nóbrega. 2013. IPTU no Brasil: Um diagnóstico abrangente, vol. 4. São Paulo: Instituto Brasiliense de Direito Publico IDP Ltda; FGV Projetos.

Afonso, José Roberto, Cristóvão Correia, Erika Amorim Araújo, Júlio Ramundo, Maurício David, and Rômulo Santos. 1998. "Municípios, arrecadação e administração tributária: Quebrando tabus.” Revista do BNDES 10:1-36.

Albertus, Michael, and Victor Menaldo. 2014. "Gaming Democracy: Elite Dominance during Transition and the Prospects for Redistribution." British Journal of Political Science 44 (3): 575-603.

Alesina, Alberto, and Edward L. Glaeser. 2004. Fighting Poverty in the US and Europe: A World of Difference. Oxford: Oxford University Press.

Andrade, Luis Aureliano de. 2007. "O município na política Brasileira: Revisitando coronelismo, enxada e voto.” In Lúcia Avelar and Antônio Octávio Cintra, eds., Sistema político Brasileiro: Uma introdução. São Paulo: Editora Unesp, 243-60.

Ardanaz, Martin, and Carlos Scartascini. 2013. "Inequality and Personal Income Taxation: The Origins and Effects of Legislative Malapportionment." Comparative Political Studies 46 (12): 1636-63.

Arretche, Marta. 2004. "Federalismo e políticas sociais no Brasil: Problemas de coordenação e autonomia." São Paulo em Perspectiva 18 (2): 12-26.

Avellaneda, Claudia, and Ricardo Gomes. 2014. "Is Small Beautiful? Testing the Direct and Nonlinear Effects of Size of Municipal Performance." Public Administration Review 75 (1): 137-49.

Bahl, Roy, and Jorge Martinez-Vasquez. 2008. "The Determinants of Revenue Performance.” In Roy Bahl, Jorge Martinez-Vazquez, and Joan Youngman, eds., Making the Property Tax Work: Experiences in Developing and Transitional Countries. Cambridge: Lincoln Institute of Land Policy, 35-57.

Baiocchi, Gianpaolo. 2006. Decentralization and Local Governance in Developing Countries: A Comparative Perspective. Cambridge, MA: MIT Press.

Barros, Ricardo, Ricardo Henriques, and Rosane Mendonça. 2000. "Desigualdade e pobreza no Brasil: Retrato de uma Estabilidade Inaceitável." Revista Brasileira de Ciências Sociais 15 (42): 123-42.

Benabou, Roland. 1996. "Inequality and Growth." In Ben Bernanke and Julio J. Rotemberg, eds., NBER Macroeconomics Annual 1996. Cambridge, MA: National Bureau of Economic Research.

Besley, Timothy, and Torsten Persson. 2009. "The Origins of State Capacity: Property Rights, Taxation, and Politics." American Economic Review 99 (4): 1218-44.

Besley, Timothy, and Torsten Persson. 2011. Pillars of Prosperity: The Political Economics of Development Clusters. Princeton, NJ: Princeton University Press.

Bird, Richard M., and Eric M. Zolt. 2008. "Tax Policy in Emerging Countries." Environment and Planning C: Government and Policy 26:73-86.

Brollo, Fernanda, Tommaso Nannicini, Roberto Perotti, and Guido Tabellini. 2013. “The Political Resource Curse.” American Economic Review 103 (5) 1759-96.

Carvalho, Pedro H. B., Jr. 2006. "O IPTU no Brasil: Progressividade, arrecadação e aspectos extra-fiscais.” IPEA Discussion paper 1251, IPEA, Brasília.

Carvalho, Pedro H. B., Jr. 2013. "Property Tax Performance in Rio de Janeiro." Journal of Property Tax Assessment and Administration 10 (4): 19-36.

Carvalho, Pedro H. B., Jr. 2015. "Distributive Aspects of Real Estate Property and Its Taxation among Brazilian Families.” IPEA Discussion paper 184. http://repositorio.ipea.gov.br/bitstream/11058/4956/1/Discussion Paper_184.pdf (accessed September 18, 2017).

Carvalho, Pedro H. B., Jr. 2017. "Property Tax Performance and Potential in Brazil." PhD thesis, Faculty of Economic and Management Sciences, University of Pretoria.
Caselli, Francesco, and Guy Michaels. 2009. "Do Oil Windfalls Improve Living Standards? Evidence from Brazil.” NBER Working paper, National Bureau of Economic Research, Cambridge, MA. https://www.nber.org/papers /w15550.pdf (accessed March 2017).

Corrêa, Letícia. 2009. “Atuação do BNDES nos investimentos na gestão do setor público: Estudo do caso Pmat-Santo André (SP).” BNDES Setorial: Setor Público 30:211-36.

De Cesare, Claudia. 2005. "O cadastro como instrumento de política fiscal." In Diego Erba, Fabrício Oliveira, and Pedro Lima Jr, eds., Cadastro multifinalitário como instrumento de política fiscal e urbana. Brasília: Ministério das Cidades.

De Cesare, Claudia. 2012. "Improving the Performance of Property Tax in Latin America." Working paper, Lincoln Institute of Land Policy, Cambridge. http://www. lincolninst.edu/sites/default/files/pubfiles/improv ing-performance-property-tax-latin-america-full_0.pdf (accessed March 2017).

De Cesare, Claudia, and Les Ruddock. 1999. “The Property Tax System in Brazil." In William McCluskey, ed., Property Tax: An International Comparative Review. Brookfield, VT: Ashgate, chap. 13, 266-82.

De Cesare, Claudia, and Martim Smolka. 2004. "Diagnóstico sobre o IPTU." Working paper, Lincoln Institute of Land Policy, Cambridge.

Estadão. 2014. "MP investiga 84 empresas beneficiárias de fraude no IPTU em SP.” http://sao-paulo.estadao.com.br/noticias/geral,mp-investiga-84 -empresas-beneficiarias-de-fraude-no-iptu-em-sp,1125251? success = true (accessed January 31, 2017).

Folha de São Paulo. 1999. "Sindicato pede abertura de inquérito." http:// www1.folha.uol.com.br/fsp/campinas/cm25029913.htm (accessed January 31,2017$)$

Folha de São Paulo. 2011. "Três vereadores são presos em Taboão.” http:// www1.folha.uol.com.br/fsp/cotidian/ff0405201118.htm (accessed January 31, 2017).

G1-Globo. 2012. "Polícia prende 13 suspeitos de fraude na arrecadação do IPTU em Cuiabá.” http://g1.globo.com/mato-grosso/noticia/2012/11 /policia-prende-13-suspeitos-de-fraude-na-arrecadacao-do-iptu-em-cuiaba .html (accessed January 31, 2017).

G1-Globo. 2013. "Escutas indicam que fiscais também fraudaram o IPTU em São Paulo." http://g1.globo.com/sao-paulo/noticia/2013/11/escutas -mostram-que-fiscais-tambem-fraudaram-o-iptu.html (accessed January 31, 2017)

Gadenne, Lucie. 2017. "Tax Me, but Spend Wisely? Sources of Public Finance and Government Accountability." American Economic Journal: Applied Economics 9 (1): 274-314.

Gomes, Ricardo, Solange Alfinito, and Pedro Albuquerque. 2013. "Analyzing Local Government Financial Performance: Evidence from Brazilian Municipalities, 2005-2008." RAC-Revista de Administracão Contemporânea 17 (6): 704-19.

Gordon, Roger, and Wei Li. 2009. “Tax Structures in Developing Countries: Many Puzzles and a Possible Explanation." Journal of Public Economics 93 (7-8): 855-66

Grin, José Eduardo. 2014. “Trajetória e avaliação dos programas federais brasileiros voltados a promover a eficiência administrativa e fiscal dos municípios." Revista de Administracão Pública 48 (2): 459-80.

Guarneri, Lucimar. 2002. Modernização da gestão pública: Uma avaliação de expêriencias inovadoras. Rio de Janeiro: BNDES.

Hoff, Peter D. 2007. "Extending the Rank Likelihood for Semiparametric Copula Estimation.” Annals of Applied Statistics 1 (1): 265-83.

IBGE (Brazilian Institute of Geography and Statistics). 2016. "IBGE Automatic Recovery System (SIDRA)." https://sidra.ibge.gov.br/home/pimpfbr /brasil. (accessed January 2016).

IPEA (Institute of Applied Economic Research). 2016. "IPEAData." http:// www.ipeadata.gov.br (accessed January 2017). 
Iversen, Torben, and David Soskice. 2006. "Electoral Institutions and the Politics of Coalitions: Why Some Democracies Redistribute More than Others." American Political Science Review 100 (2): 165-82.

Kelly, Roy. 2013. "Property Tax Collection and Enforcement." In William J. McCluskey, Gary C. Cornia, and Lawrence C. Walters, eds., A Primer on Property Tax: Administration and Policy. West Sussex: Blackwell, chap. 6, 141-71.

Kenworthy, Lane, and Jonas Pontussen. 2005. "Rising Inequality and the Politics of Redistribution in Affluent Countries." Perspectives on Politics 3 (3): 449-71.

Limongi, Fernando, José Antonio Cheibub, and Argelina Figueiredo. 2015. "Participação política no Brasil." In Marta Arretche, ed., Trajetórias da desigualdade: Como o Brasil mudou nos Últimos cinquenta anos. São Paulo: Editora Unesp/CEM, chap. 1, 23-50.

Litschig, Stephan, and Kevin Morrison. 2013. "The Impact of Intergovernmental Transfers on Education Outcomes and Poverty Reduction." American Economic Journal: Applied Economics 5 (4): 206-40.

Meltzer, Allan H., and Scott F. Richard. 1981. "A Rational Theory of the Size of Government.” Lournal of Political Economy 89 (5): 914-27.

Moene, Karl Ove, and Immanuel Wallerstein. 2001. "Inequality, Social Insurance, and Redistribution." American Politial Science Review 95 (4): 859-74.

Monteiro, Joana, and Claudio Ferraz. 2012. "Does Oil Make Leaders Unaccountable? Evidence from Brazil's Offshore Oil Boom.” Working paper, Brazilian School of Public Administration and Business (FGV/ EBAPE). http://www.parisschoolofeconomics.eu/docs/ydepot/semin/tex te1213/CLA2012DOE.pdf (accessed March 2017).

National Treasury (DFOFM). 2017. “Municipal Expenditure.” Brazilian Ministry of Finance, Brasília.

Nickson, R. Andrew. 1995. Local Government in Latin America. Boulder, CO: Lynne Rienner.

Nicolau, Jairo. 2012. Eleições no Brasil: Do império aos dias atuais. Rio de Janeiro: Zahar.

Oster, Emily. 2019. "Unobservable Selection and Coefficient Stability: Theory and Evidence." Journal of Business and Economic Statistics 37 (2): 187-204.
Perotti, Roberto. 1996. "Inequality, Redistribution and Growth: What the Data Say." Iournal of Economic Growth 1 (2): 149-87.

Persson, Torsten, and Guido Tabellini. 2003. Economic Effects of Constitutions. Cambridge, MA: Cambridge University Press.

Power, Timothy, and Cesar Zucco Jr. 2009. "Estimating Ideology of Brazilian Legislative Parties, 1990-2005: A Research Communication.” Latin American Research Review 44 (1): 218-46.

Power, Timothy, and Cesar Zucco Jr. 2012. "Elite Preferences in a Consolidating Democracy: The Brazilian Legislative Surveys, 1990-2009.” Latin American Politics and Society 54 (4): 1-27.

Rodríguez, Alfredo, and Fabio Velásquez, eds. 1995. Municípios y servícios públicos: Gobiernos locales en ciudades intermédias de América Latina. Santiago: Ediciones Sur.

Romer, Thomas. 1975. "Individual Welfare, Majority Voting, and the Properties of a Linear Income Tax." Lournal of Public Economics 4 (2): 163-85.

Saiegh, Sebastián. 2015. "Using Joint Scaling Methods to Study Ideology and Representation: Evidence from Latin America." Political Analysis 23 (3): 363-84.

Samuels, David. 2004. “The Political Logic of Decentralization in Brazil." In Alfred Montero and David Samuels, eds., Decentralization and Democracy in Latin America. Notre Dame, IN: University of Notre Dame Press, 67-93.

Samuels, David, and Cesar Zucco Jr. 2014. "The Power of Partisanship in Brazil: Evidence from Survey Experiments." American Journal of Political Science 58 (1): 212-25.

Scheve, Ken, and David Stasavage. 2006. "Religion and Preferences for Social Insurance." Quarterly Journal of Political Science 1 (3): 255-86.

Smolka, Martim, and Fernanda Furtado. 1996. "Argumentos para a reabilitação do IPTU e do ITBI como instrumentos de intervenção urbana (progressista)." Revista Espaço \& Debates 39 (16): 87-103.

Souza, Pedro, and Marcelo Medeiros. 2015. "Top Income Shares and Inequality in Brazil, 1928-2012." Journal of the Brazilian Sociological Society 1 (1): 119-32.

TSE do Brasil. 2016. “Tribunal Superior Eleitoral do Brasil.” http://www .tse.jus.br/ (accessed January 2017). 